\title{
7. Ways of knowledge transfer
}

Royals, princes, ambassadors and delegates in the sixteenth and seventeenth centuries in Central Europe used ciphers, code words, and signs for the syllables when exchanging diplomatic and political information with each other. Ferenc Rákóczi II applied a complex homophonic system when discussing his love affair in French with his political ally and lover, Elżbieta Helena Sieniawska (1669-1729), wife of a Polish palatine. ${ }^{1}$ His generals, Sándor Károlyi and Miklós Bercsényi, used a vulnerable monoalphabetic system of graphic symbols to arrange military business. ${ }^{2}$ An even simpler method was applied by the poet Bálint Balassi a hundred years earlier to conceal intimate family business, a cipher that assigned the first half of the alphabet to the letters of the second half and vice versa. ${ }^{3}$ The would be palatine István Illésházy only enciphered the vowels in his private letter to his wife, Katalin Pálfy in his exile in 1605, and even those in a well-recognizable fashion. ${ }^{4}$ The merchant Zsigmond Szaniszló also codd ed private affairs - financial details, names of certain people, a few liberal comments, his wife's extramarital affair - in his lengthy diary between 1682 and 1711. Like Illésházy, he only coded the vowels, so this ciphertext can be decoded at first reading. ${ }^{5}$ The Transylvanian politician, Gábor Haller covt ered up his private secrets in his diary from between 1630 and 1644 - his alcoholism, marriage plans, details of his bedtime fantasies - using two different ciphering methods, one similar to the pigpen method of the Freemasons, consisting of dots and squares, and another one based on letter transposition. ${ }^{6}$

The question is inescapable: where did these people acquire their knowledge on cryptography, their practical skills on the use of ciphers?

Research in the past two decades in the history of science has increasingly focused on the ways and methods of knowledge transfer, especially

\footnotetext{
1 On this case, see more below.

2 The key: War History Archives E. 1705/18; the letters: E. 1705/5, 6, 03, 16, 17, Bercsényi's key with Rákóczi: AR I. vol. 4. Appendix

3 Révay, Titkosírások, 69-73; Révay, II. Rákóczi Ferenc, 41-46. Béla Stoll, ed. Balassi Bálint, Összes versei (Poems of Bálint Balassi) (Budapest, Helikon, 1974): 260-271; 391-394.

4 István Vadai, "Két XVII. századi titkosírás megfejtése."

5 Károly Torma, ed. Történelmi Tár(Historical documents), 1889 (12). 230-269, 503-522, 708-727, (13), 1890. 77-101, 307-327, 493-510, 757-770, (14), 1891. 267-295.

6 Károly Szabó, ed. Erdélyi Történelmi Adatok (Historical data from Transylvania) 4 (Kolozsvár: Erdélyi Múzeum Egyesület, 1862): 1—103
} 
of passing on technological skills. ${ }^{7}$ Which channels were primarily used: written, by means of books and letters, or personal, by means of schools and master-student relationships? Is the transfer of technological skills collective, based on the mobility of groups of artisans, or individual, based on the mobility and migration of particular experts, engineers, technological professionals? How is knowledge transferred in those areas where the details of theory and practice can be easily and explicitly expressed in writing, and how is it passed on in areas where a skill can only be learned implicitly, through practice and training? ${ }^{8}$ Is it possible to follow the spread of a technology in the past across diverse geographical areas and across various knowledge-transfer communities, institutions and markets? How did these communities interact with the given technological information and how did they change it in the process of interpreting and applying the given knowledge to their local needs? How was circulation affected by the unavoidable translation processes? ${ }^{9}$

Can these ways of knowledge transfer be reconstructed at all? What sources provide reliable information on the circulation of such techniques that were hardly recorded and codified in their own times? And what about those crafts that were secretive both in their techniques and in their field of application $?^{10}$

There were several possible sources of cryptographic knowledge in early modern Hungary. Up-to-date handbooks were available in libraries in the following three fields:

1) secret writings in the strictest sense in reference books on cryptography and steganography,

7 On the issue of knowledge transfer in history of technology, see: Liliane Hilaire-Pérez and Catherine Verna, "Dissemination of Technical Knowledge in the Middle Ages and the Early Modern Era: New Approaches and Methodological Issues," Technology and Culture 47 (2006): 536-565; Liliane Hilaire-Pérez and Anne-Francoise Garcon eds., Les chemins de la nouveauté: Inventer, innover au regard de l'histoire (Paris, 2004).

8 Ricardo Cordoba, ed., Craft Treatises and Handbooks: The Dissemination of Technical Knowledge in the Middle Ages (Turnhout: Brepols, 2013).

9 Josef Ehmer, "Worlds of Mobility: Migration Patterns of Viennese Artisans in the Eighteenth Century," in Geoffrey Crossick, ed., The Artisan and the European Town, 1500-19oo (Aldershot, U.K., 1997), 172-99; Stephan R. Epstein, "Journeymen, Mobility, and the Circulation of Technical Knowledge, XIVth-XVIIIth Centuries," in Liliane Hilaire-Pérez and Anne-Francoise Garcon eds., Les chemins de la nouveauté: Inventer, innover au regard de l'histoire (Paris, 2004): 1-30, Michel Cotte ed. Les circulations techniques: En amont de l'innovation - hommes, objets et idées en mouvement (Belfort/ Besancon, France, 2004).

10 John R. Harris, Industrial Espionage and Technology Transfer: Britain and France in the 18th-Century (Aldershot, U.K., 1998). 
2) artificial languages, which had a flourishing literature in this period,

3) the systems of speedwriting, stenography.

Two further possible sources should also be analysed

4) the Arabic written knowledge due to the Turkish neighborhood, because the practice of cryptography and codebreaking were a good five hundred years older in the Arab world than in Europe,

5) and finally, the proximity and effect of the everyday diplomatic practice should also be considered.

\subsection{Handbooks of cryptography}

People interested in the technology of ciphers could have found a variety of printed handbooks in the libraries of the early modern period: the Polygraphia and Steganographia of Johannes Trithemius," De occultis literarum notis by Giambattista Della Porta, ${ }^{12}$ Cryptomenytices et cryptographiae libri IX of Gustavus Selenus, the famous library founder, Prince August of Braunschweig, ${ }^{13}$ and Traicte des Chiffres by Blaise Vigenère ${ }^{14}$ were all available in print by the beginning of the seventeenth century. These were followed by the Polygraphia of Athanasius Kircher, ${ }^{15}$ and the Rules for explaining and deciphering all manner of secret writing by Englishman John Falconer. ${ }^{16}$ These reference books, especially those five by Trithemius, Porta, Vigenère, Selenus and Kircher must have been the crown jewels in the libraries of every fan of cryptology, offering a wide range of methods from monoalphabetic substitution through transpositional to polyalphabetic and other highly advanced methods.

It makes sense to suggest - as historians Zoltán Révay ${ }^{17}$ and Ágnes R. Várkonyi ${ }^{18} \mathrm{did}$ - that one of these early modern monographs, that by Athanasius Kircher could have been an important source of Hungarian

11 Johannes Trithemius, Polygraphiae libri sex (Oppenheim: Haselberg de Aia, 1518), Steganographia: ars per occultam scripturam (Frankfurt: Becker, 16o6).

12 Giambattista Della Porta, De furtivis literarum notis vulgo de ziferis liber quinque (Naples: Johannes Baptista, 1602), De occultis literarum notis, seu artis animi sensa occulte aliis significandi (Starssbourg: Zetzner, 16o6).

13 Gustavus Selenus, Cryptomenytices et cryptographiae libri IX (Luneburg, Sternen, 1624).

14 Blaise de Vigenère, Traicte des Chiffres (Paris: Abel l'Angelier, 1586).

15 Athanasius Kircher, Polygraphia nova et universalis (Roma: Typographia Varesij, 1664).

16 J. Falconer, Rules for explaining and deciphering all manner of secret writing (London: Printed for Dan. Brown ... and Sam. Manship, 1692).

17 Révay, Titkosírások, 89 and 110.

18 R. Várkonyi Ágnes, A rejtőzködő murányi Vénusz (Budapest: Helikon, 1987), 213. 
cipher use. To confirm this, one should look at first how easily accessible these or similar handbooks on cryptology were in the private libraries and church collections. But the results of a methodical investigation into early modern library catalogues will be disappointing. There is no proof that early cryptologists were acquiring their methods from these handbooks. While noblemen applied cryptographic methods relatively frequently, there is hardly any reference literature of it in their libraries.

Pál Ráday, the head of the chancellery of the Rákóczi freedom fight is one example. There are few people in Hungarian history who have seen more ciphered messages than he did, he had separate cipher keys with a number of ambassadors and European rulers. There are thirty-one extant tables from the period of the freedom fight in the family archives of the Rádays, ${ }^{19}$ and ninety-nine in the secret archive of Rákóczi. ${ }^{20}$ Even if the number of double copies is subtracted from the sum of these two, there are still several dozens of different cipher techniques that were employed by him (or his secretaries) on a daily basis.

What about his library? Thorough research has adequately reconstructed it. ${ }^{21}$ Ráday built up his collection through careful choices, it reflects his good taste (and that of his son, Gedeon). He had borrowed the help of academics to guide him in increasing his collection, ${ }^{22}$ and had enriched it with encyclopaedic completeness in more than one field, such as history, law or politics. ${ }^{23}$ The literature of cryptography, however, is completely missing from the library.

A similar example is that of András Dudith from over a century before Ráday, who had used cipher keys extensively in his numerous envoy's reports to the court in Vienna. ${ }^{24}$ His library has not totally been reconstructt ed, yet research has found no trace of a handbook on cryptography in his library yet. ${ }^{25}$

\footnotetext{
19 Ráday Archives C64-4d2-25.

20 MNL OL G 15 Caps. C. Fasc 43. and Fasc. 44.

21 Györgyi Borvölgyi, Ráday Pál (1677-1733) könyvtára (Library of Ráday Pál (1677-1733))

(Budapest, OSzK, 2004).

22 Ibid. 63.

23 Ibid. 80-84.

24 ÖStA HHStA Staatskanzlei Interiora Ceremonie und courtoisie und Chiffren schlüssel: Kt. 12. Nr. 172, published: Lech Szczucki, Szepessy Tibor, eds. Epistulae / Andreas Dudithius, vol. 1, 40-41, see also vol. 2, 22-23; vol. 3, 16-17; vol. 4, 18-22.

25 József Jankovics, István Monok, eds., Dudith András könyvtára (Library of Andreas Dudith) (Szeged: Scriptum, 1993).
} 
Johann Heinrich Bisterfeld sent a high number of enciphered messages to Zsigmond Rákóczi. ${ }^{26}$ If the Ráday library was said to have been carefully selected, this is even more true for the library of Bisterfeld. He was one of the major encyclopedic minds of his age. As a professor at Herborn and later Alba Iulia (Gyulafehérvár), he built a well-structured library and even had a lasting influence on the book-collecting practice of Zsigmond Rákóczi. ${ }^{27}$ And although some books of Giambattista Della Porta and Athanasius Kircher were undeniably there in his library, not the ones on cryptography, as any other books on cryptography are not there either. ${ }^{28}$ One can assume, of course, that Bisterfeld had gained his cryptographic knowledge from his colleague and father-in-law, the other famous encyclopedist, Johann Heinrich Alsted. ${ }^{29}$ Alsted's Encyclopaedia does indeed contain a chapter entitled Polygraphia, in the last, seventh, volume, among the "miscellaneous sciences", in the section called "Farragines disciplinarum, seu disciplinas compositas", under "Mnemonica", following the part on the combinatorial method of Raimundus Lullus, called "Ars lulliana" ${ }^{30}$ This little section, howw ever, only makes up one page, while tobacco is discussed in two pages under Tabacologia. Alsted's short section on Polygraphia explains the polyalphabetic table of Trithemius in a period when the polyalphabetic methods were way too complex to be applied in actual practice - theory and practice were not in touch. Homophonic ciphers are not even mentioned.

No cryptographic handbook was found in the reconstructed family libraries of the Rákóczis ${ }^{31}$ or Telekis ${ }^{32}$ either, despite the fact that Prince György Rákóczi I had used ciphers extensively, and Mihály Teleki's ciphered messages had survived in the hundreds, some of which he had even

26 Sándor Szilágyi, "Herceg Rákóczy Zsigmond levelezése," (Correspondence of Prince Zsigmond Rákóczy) MTT III/10. 654-676.; MTT III/11. 289-300.; MTT III/13. 229-257.

27 Noémi Viskolcz, ed., Johann Heinrich Bisterfeld (1605-1655). Bibliográfia, A Bisterfeld könyvtár (Johann Heinrich Bisterfeld (1605-1655). Bibliography, The Bisterfeld library) (Budapest - Szeged: OSZK, Scriptum, 2003.), 91.

28 Ibid.

29 Howard Hotson, Johann Heinrich Alsted 1588-1638: Between Renaissance, Reformation, and Universal Reform (Oxford: Clarendon Press. 200o); idem, Paradise postponed. Johann Heinrich Alsted and the Birth of Calvinist Millenarianism (Dordrecht-Boston-London: Springer, 2001).

30 Ioan. Henrici Alstedii, Encyclopaedia septem tomis distincta (Herbornae: 1630. and Lugd. Batav: 1640.) Repr: Wilhelm Schmidt Biggemann, ed., Johann Heinrich Alsted: Encyclopaedia septem tomis distincta. Stuttgart-Bad Cannstatt, 1989-1990).

31 István Monok, ed., A Rákóczi-család könyvtárai, 1588-1660 (Libraries of the Rákóczi family) (Szeged: Scriptum, 1996).

32 István Monok, Noémi Németh, András Varga, eds. Erdélyi Könyvesházak III. 1563—1757: A Bethlen-család és környezete, Az Apafi-család és környezete, A Teleki-család és környezete, Vegyes források (Transylvanian libraries, the Bethlen, Apafi and Teleki libraries) (Szeged, Scriptum, 1994). 
written in his own hand. The reconstruction of these libraries is not complete, so this result is not final either. It is still significant that the research has not found many things so far. One of the few exceptions is one item of the 1638 description of Máté Csanaki's library: De occultis literarum Notis Johanne Baptista Porta Neapolithano Authore. ${ }^{33}$ Csanaki (1594-1636) was the court physician of György Rákóczi I and a rector at Cluj Napoca, Romania (Kolozsvár). On returning from abroad, he left his books in Gdansk and after his death it was the prince who bought them and had them delivered to Sárospatak. Since the Sárospatak library already had many of these books, they were finally taken to Alba Iulia, (Gyulafehérvár) in Transylvania. ${ }^{34}$ Bisterfeld himself was excited at the prospect of receiving the collection. One can therefore assume that György Rákóczi I must have had a copy of Della Porta's book, although no influence of it can be detected on the ciphering practice of the prince (he used many monoalphabetic ciphers and few homophonic ones. $)^{35}$

Another of the few cryptographic resources that have been found is the 1678 Viennese booklist of Ferenc Nádasdy. An item here is the 1608 Frankfurt edition of Trithemius's Steganographia.$^{36}$ One is inclined to supp pose that the magnate Nádasdy, Judge Royal and a participant of the Wesselényi movement, applied in his cryptographic practice whatever he had learned from Trithemius, but there is no evidence for it. His enciphered messages either use a monoalphabetic system ${ }^{37}$ with code words, nomenn clatures, or a homophonic, ${ }^{38}$ which was more up-to-date in that time, bearr ing no sign of the complex methods suggested by Trithemius. It is important to note, however, that research in this field has not yet been completed and might still bring up further evidence.

The rest of the cryptographic relevant books were found in collections whose owner - or the church establishment behind them - are not known for applying ciphers. Though we cannot exclude the possibility, there is no

33 Ibid., 183 .

34 István Monok, “Csanaki Máté könyvjegyzéke” (Booklist of Máté Csanaki) Magyar Könyvszemle (1983): 256-262.

35 Ágoston Ötvös, Rejtelmes levelek első Rákóczy György korából.

36 Gábor Farkas, András Varga, Tünde Katona, Miklós Latzkovits, István Monok, eds., Magyarországi magánkönyvtárak II. 1588-1721 (Hungarian private libraries II. 1588-1721) (Szeged: Scriptum, 1992.), 103. See also Rita Bajáki, Hajnalka Bujdosó, István Monok, Noémi Viskolcz, eds., Magyarországi magánkönyvtárak IV. 1552-1740. (Hungarian private libraries IV. 1552-1740 (Budapest: OSZK, 2009).

37 HHStA, Ung Akt. Spec Verschwörerakten IV. Nádasdysche Akten Fasc. 314. Konv. B. 1671. I-III. fol. $76-78$.

38 HHStA, Ung Akt. Spec Verschwörerakten IV. Fasc. 312. Konv. A. fol. 4. 
indication that these books were ever used as handbooks. One such find is the item De occultis literarum notis by Della Porta that is listed twice in the 1632 catalog of the Jesuit library in Trnava (Nagyszombat, Slovakia), and another is Poligraphia, octavo, Argentorati, 1600 by "Trithemij Abbatij" in the 1690 catalog, also listed twice (perhaps once existing in two volumes), in the section Scriptura sacra, et patres (presumably by mistake). ${ }^{39}$ The Polygraphia of Trithemius (Polygraphie libri sex and Clavis polygraphiae, 1518) could be found in the collection of Hans Dernschwam, ${ }^{40}$ the humanist scholar who died in Hungary in 1568 , as well as in the library of Sárospatak, ${ }^{41}$ and, according to the list of $1679-168$ o, in the school library of Nagyenyed. ${ }^{42}$

Previous literature has supported the claim that the works of Athanasius Kircher (1602-166o) had had a lasting influence on Hungarian cryptographic practice. This statement should be investigated carefully. Kircher, the pride of the Jesuit order, was one of the most prolific authors of his time. A professor of Eastern languages and mathematics in Avignon, he later went to Rome to become professor of the Collegium Romanum. He might have been the first person to realize the opportunities involved in the mass printing of books. With the help of a publishing company in Amsterdam, he compiled several encyclopediae covering every possible aspect of classic and modern knowledge, chockablock with linguistic, paleographic, historic and scientific data. During the fifty years of his career he had written almost thirty books. He was in correspondence with all of Europe, and even the transcontinental parts of the world. He was the friend of popes and princes. Bishops, archbishops and aristocrats supported him, borrowed books from him and provided him with academic information. Relying on the resources of the Jesuit order, he created an information network that covered the whole world from China to South America. His correspondents delivered him data on everything from local volcanoes to magnetic fields, and to writing systems. ${ }^{43}$

39 Farkas Gábor Farkas, ed. Magyarországi jezsuita könyvtárak 1711-ig, II, Nagyszombat 1632-169o (Hungarian Jesuit libraries til 1711, II, Nagyszombat 1632-169o) (Szeged, Scriptum, 1997.), 96-97 and 321 .

40 Jenő Berlász, Katalin Keveházi, István Monok, András Varga, eds., A Dernschwam-könyvtár: Egy magyarországi humanista könyvjegyzéke (The Dernwchwam library, booklist of a humanist from Hungary) (Szeged: JATE, 1984), 19.

41 Róbert Oláh, ed. Protestáns Intézményi Könyvtárak Magyarországon, 1530-1750 (Protestant institutional libraries in Hungary, 1530-1750) (Budapest: OSZK, 2009), 281.

42 István Monok, ed., Erdélyi Könyvesházak II: Kolozsvár, Marosvásárhely, Nagyenyed, Szászváros, Székelyudvarhely (Transylvanian Libraries II: Kolozsvár, Marosvásárhely, Nagyenyed, Szászváros, Székelyudvarhely) (Szeged: Scriptum, 1991), 151.

43 John Edward Fletcher, Athanasius Kircher und seine Beziehungen zum gelehrten Europa seiner Zeit (Wiesbaden: Otto Harrassowitz, 1988); Paula Findlen, Athanasius Kircher: The Last Man Who 
Kircher was enthralled by automata and impressed a many rulers with the clever devices he had designed. He had a grand collection in Rome that attracted scientifically minded visitors from faraway lands. Kircher guided his visitors around this exceptional collection of various oddities himself: machines, wooden obelisks, children's skeletons, dissected animals, Roman burial pots, Chinese objects, mosaics or coins.

He was also a renown codebreaker, sending cryptographic puzzles to his correspondents and also receiving some undeciphered texts. At one point his library included perhaps the most enigmatic book of all times, the manuscript that was later named Voynich after the person who rediscovers it almost two hundred and fifty years later (Wilfrid Voynich, 1865-1930). Kircher examined the book famous for its drawings on botanics and astronomy, naked bathing ladies and a special writing system, and wisely decided to put it aside instead of being put to shame with an incorrect bluff of a solution. And right he was. Not even elite WWII codebreakers had success with the manuscript, despite their much richer resources, and the text has not been broken to this day. ${ }^{44}$

Kircher's 1663 book on cryptography, entitled Polygraphia Nova et Universalis, was printed in limited numbers, in accordance with the author's intention. It was then sent to a limited number of royals and other dignitaries, accompanied by a private letter. Most if it is not even on ciphers, it is rather a Polygraphia following the track of Trithemius, i. e. a means of communication that is meant to override the linguistic chaos of Babel. It creates an extensive multilingual dictionary by assigning the same number to the words of different languages with the same meaning. This way, if a scribe writes down the numbers corresponding to the words of a German sentence, a reader who does not even speak German may still be able to read it, for example in Italian. A seventeenth century translating software. The system is designed to ease communication, but book three of the volume also gives advice on how to conceal the content of a text. Here a description of the letter substitution and permutational methods by Trithemius and Vigenère are described. Artificial languages and cryptography walked hand in hand. ${ }^{45}$

Knew Everything (New York: Routledge, 2004); Joscelyn Godwin, Athanasius Kircher's Theatre of the World: The Life and Work of the Last Man to Search for Universal Knowledge. (Rochester, Vt.: Inner Traditions, 2009).

44 Gerry Kennedy, Rob Churchill, The Voynich Manuscript: The Mysterious Code That Has Defied Interpretation for Centuries (Rochester, VT; 2006).

45 On Kircher's Polygraphia: Nick Wilding, "If you have a secret, either keep it, or reveal it": Cryptography and Universal Language' in Daniel Stolzenberg, ed., The Great Art of Knowing - The Baroque Encyclopedia of Athanasius Kircher (Fiesole: Stanford University Libraries, Edizioni 
Kircher had contacts in Hungary - friends, correspondents, followers. ${ }^{46}$ He dedicated a chapter to Ferenc Nádasdy and Archbishop György Lippay, respectively, in his book on Egypt. Many aristocrats, including counts Batthyány and Erdődy had visited him in Rome. The topic of his correspondence with Nádasdy was the design of telescopes, he even sent him an astronomical telescope. He received mining information from the Jesuits in Nagyszombat for his book on the underground world regarding various ores, underground waters, and cave dwarfs. Several of his books could be found in the Zrínyi library too, including Oedipus Aegyptiacus, a book that contained his solutions of the hieroglyph, and De Magnetica Arte libri tres on the phenomenon of magnetism. ${ }^{47}$ Lippay had read several of his books, including a few that the Jesuit scholar himself had sent to him. Imre Jakusith, lord of Oroszlánkő, who also collected Kircher's books, was corresponding with the scholar, who had sent him the complete list of his books in response. Today, altogether ninety-six copies of thirty different works of Kircher can be found or identified in libraries in Hungary. ${ }^{48}$

This means that Kircher was well-known among the circles of the Hungarian literati. But could he have become a source of the local knowledge on cryptography? Only one of his books, and only one part of that, dealt explicitly with the field of cryptography. The topic of code does emerge in his other books too, but never in such depth that would allow a reader to learn the actual practices of ciphering from it. However, this only book, the Polygraphia was among the least known volumes of Kircher in Hungary. To our best knowledge, it was not part of the Zrínyi library. A note by Jakusith says that this book was missing from his collection. Only one copy of it can be identified in Hungary, the one sent by Kircher to Archbishop Lippai. This copy has been in the Library of the Esztergom Primate since then. ${ }^{49}$

Cadmo, 2001), 93 - 103; idem, "Publishing the Polygraphy: Manuscript, Instrument, and Print in the Work of Athanasius Kircher' in Paula Findlen, ed. Athanasius Kircher, 283-296; Daniel Stolzenberg, "The Universal History of the Characters of Letters and Languages: An Unknown Manuscript by Athanasius Kircher," Memoirs of the American Academy in Rome 56/57 (2011/2012): 305-321.

46 Gábor Kiss Farkas "Difficiles Nugae' Athanasius Kircher magyarországi kapcsolatai" ('Difficiles Nugae' Kircher's contacts in Hungary), Irodalomtörténeti Közlemények 109 (2005): 436-463.

47 Gábor Hausner, Tibor Klaniczay, Sándor Iván Kovács, István Monok, Géza Orlovszky, eds., A Bibliotheca Zriniana története (History of the Bibliotheca Zriniana) (Budapest: Argumentum Kiadó, 1992,) 324-326. Kircher's books in the library: Oedipus Aegyptiacus (1652),Jesu Magnes, sive de Magnetica Arte libri tres (1654) Ars magna lucis (1646) Scrutinium Physico-medicum (1658).

48 Kiss Farkas, "Difficiles Nugae" 457.

49 Esztergomi Főszékesegyházi Könyvtár (Archiepiscopal Library of Esztergom) Ms 28879: Kiss Farkas "Difficiles Nugae" 443. 
All in all, Selenus and Vigenère were hardly known, whereas Della Porta, Trithemius and Kircher were rather familiar names in seventeenth-century Hungary. Their works could quite easily be found. Porta and Kircher, however, were not famous in Hungary for their cryptographic works. Porta was better known by his Magia naturalis (Antwerpen: 1560), while Kircher by his Oedipus Aegyptiacus (I-II, Rome, 1652-54). In addition, all these authors were rather interested in the more sophisticated and advanced technologies of cryptography: combinatorial polyalphabetic ciphers consisting of several alphabets and requiring a great deal of intellectual capacity. Diplomatic, political, military or private ciphers of the time, however, did not use these complex technologies but stayed on the level of monoalphabetic and the more progressive homophonic cipher. But the homophonic ciphers used, among others, by Miklós Zrínyi ${ }^{50}$ and György Lippay, ${ }^{51}$ were not covered in these handbooks, while those monoalphabetic methods that assigned the first half of the alphabet to the second half, or that only exchanged vowels for code signs were considered so outdated that they were not even mentioned. Certain cipher users might possibly have seen Trithemius' or Kircher's Polygraphia or perhaps De occultis literarum notis by Della Porta, but there is no sign that they developed or modified their earlier methods on the basis of their readings. Quite clearly, the source of their cryptological knowledge is to be found elsewhere.

\subsection{Artificial languages}

Several authors created universal, perfect, philosophical or artificial languages for a number of purposes in the mid-seventeenth century (Kircher being one of them). ${ }^{52}$ This is roughly the same group of intellectuals who

50 Károly Széchy, Gróf Zrínyi Miklós (Count Miklós Zrínyi) (Budapest: Franklin, 1896-1902) vol. 3. 335-338, vol. 4. 252-268.

51 Antal Beke, ed., "Pázmány, Lippay és Eszterházy levelezése I. Rákóczy Györgygyel [1629-1637]. 1-3." ("The correspondence of Pázmány, Lippay and Eszterházy with György Rákóczy I [1629-1637]. 1-3." Magyar Történelmi Tár (1881): 641-674, (1882):134-148, 279-325, the key: 144-146. $5^{2}$ Louis Couturat, Leopold Leau, Histoire de la langue universelle (Hachette, Paris, 1903); Les nouvelles langues internationales (Hachette, Paris, 1907); Arno Borst, Der Turmbau von Babel: Geschichte der Meinungen über den Ursprung und Vielfalt der Sprachen und Völker (Hiersemann, Stuttgart, 1957-1963); Paolo Rossi, Clavis universalis: arti della memoria e logica combinatoria da Lullo a Leibniz (Bologna: il Mulino, 1983), James Knowlson, Universal Language Schemes in England and France, 1600-180o (Toronto, University of Toronto Press, 1975), Roberto Pellerey, Le lingue perfette nel secolo dell'utopia (Roma-Bari: Laterza, 1992), Mary M. Slaughter, Universal languages and scientific taxonomy in the 17th century (Cambridge: Cambridge University Press, 1982), Umberto Eco, La ricerca della lingua perfetta nella cultura europea (Bari: Laterza, 1993). 
have authored the major works on cryptography, almost all belonging to the leading literati of the early modern era: Johannes Trithemius, Athanasius Kircher, René Descartes, Isaac Newton, Gottfried Wilhelm Leibniz, Marin Mersenne, George Dalgarno, Joseph de Maimieux, Francis Lodwick, Cave Beck, John Wilkins, or the Hungarian György Kalmár..$^{53}$ Their purposes might have differed. One of them wanted to design a practical, user-friendly common language, while the other wished to create a logically structured tool suitable for establishing human knowledge philosophically. One of them was looking for Adam's lost language, and others, like Kircher or Cave Beck, designed a common writing system that everybody could read in their own language.

All of these designs aimed at making language available and accessible, they were open projects, by nature not secretive, fundamentally different from secret writing designs. ${ }^{54}$ Still, the two seemingly opposite trends contained many common elements. The authors are often identical, who found the creation of a useful artificial language as thrilling as the secrecy offered by more practical ciphers. ${ }^{55}$ Another similarity is that an artificial language without its structural description and vocabulary is pretty much like an unbroken cipher.

There is a third reason to consider the impact of artificial language designs. While most cipher tables assign code symbols to letters, syllables or to code words, there are a few cipher keys where grammatical elements also appear, such as the sign for accusativus, genitivus, dativus and ablativus, or for plural. These often appear as graphic symbols in a table consisting otherwise of number codes. There are two examples for such symbols among Mihály Teleki's tables. ${ }^{56}$ These grammatical categories are widespread in arf tificial languages, for example in those of Wilkins, Della Porta, Kircher and others. Theirs are, of course, more complex systems than the cipher keys: Kircher's Polygraphia for instance applies graphic signs for declination and conjugation too. ${ }^{57}$ I have yet to find any trace of conjugation in code keys, just as there is no direct evidence that the appearance of declination items in cipher keys in the second half of the seventeenth century can be directly

See more details: Benedek Láng, The Rohonc codex, forthcoming.

54 Cave Beck, The Universal Character by which all the Nations in the World may Understand one anothers conceptions, Reading out of one Common Writing their own mother tongues (London: Thomas Maxey, 1657); Athanasius Kircher, Polygraphia Nova et universalis ex combinatoria arte detecta (Rome: Varesius, 1663).

55 On the common history of artificial languages and cryptography, see Strasser, Lingua Universalis.

56 MNL OL P 1238 Mihály Teleki Collection. Miscallenous documents. Cipher keys.

57 Kircher, Polygraphia nova, 15. 
linked to artificial languages. One can entertain the idea of such relationship, but one also needs further evidence supporting such assumptions. Whether the designers of cipher keys had read artificial language schemes is a question that cannot be decided without further evidence.

\subsection{Stenography}

The connection between Hungarian cryptographic practice and stenography, i.e. shorthand has been recognized as early as in the nineteen thirties..$^{58}$ The same secretaries were recording the political speeches and the drafts of the letters with speedwriting, who were encrypting the classified information according to a particular code key - creating an obvious link between the two areas. The father of one of the earliest stenographic methods, John Willis himself underlines the fact that his method could in fact be used as a cryptologic method, as it hides information well from those who are unfamiliar with it. ${ }^{59}$ Several books covered the two fields together in the nineteenth, and in the twentieth century too. ${ }^{60}$ Examples testify that a stenographic note without its character table might become a real secret writing, either in accordance with, or contrary to, the intentions of its author. ${ }^{61}$ But was there any actual relationship between the two areas in the sixteenth and seventeenth centuries?

These two centuries constitute a blind spot in the Hungarian history of stenography. Shorthand symbols, in other words, Tironian notes (notae Tironianae) were most widespread during the late antique and early medieval periods, when letter-writing was especially laborious. The system became more sophisticated by the twelfth century when it had several thousand signs, including signs concepts. By the later medieval period, however, normal Latin writing became fluent enough, abbreviations and truncations were becoming more general, making Tironian notes less

$5^{8}$ László Siklóssy, Az országgyülési beszéd útja (Budapest: Királyi Magyar Egyetemi Nyomda, 1939), 30-45.

59 John Willis, The Art of Stenographie, teaching by plaine and certaine rules, to the capacitie of the meanest, and for the use of all professions, the way of compendious writing (London, Cuthbert

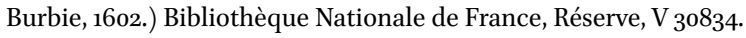

6 o.g. Giorgio Costamagna, Tachiografia notarile e scritture segrete medioevali in Italia (Rome: ANAI, 1968).

61 E.g. James J. Gillogly, "Breaking an Eighteenth Century Shorthand System", Cryptologia 11/2 (1987): 93-98 and Emanuele Viterbo, "The Ciphered Autobiography of a 19th Century Egyptologist," Cryptologia, 22/3 (1998): 231-243; Géza Gárdonyi, Titkosnapló (Secert diary) (Budapest: Szépirodalmi, 1974). 
indispensable. Shorthand symbols practically disappeared. There is a gap in the history of stenography for the next couple of centuries, until it was rediscovered in the sixteenth century. Fifteenth-century Italian scribes developed their own shorthand methods to record official speeches, mostly sermons, still, we consider three early modern authors the new founding fathers of shorthand: Timothy Bright (Characterie; An Arte of Shorte, Swifte and Secrete Writing by Character, 1588), John Willis (Art of Stenography, 1602), and Thomas Shelton (Short-Writing, 1626, in later editions: Tachygraphy). Their systems often only had individual signs for the consonants. Vowels were only indirectly indicated, by the position of the following consonant, its width, or the surrounding dots, for example. Roughly one hundred and fifty to two hundred signs were used in these systems, making them similar in size to an average homophonic cipher.

While modern shorthand systems were born in England around 16oo, the first Hungarian handbooks only appeared a hundred and fifty to two hundred years later, it seems. The early centuries of Hungarian stenography lack a reliable overview, but as of present, there is no sign that there was such a complex system of shorthand for recording political speeches that could have had a lasting influence on the encryption methods. On the contrary, ciphering seems to have been more developed than stenography.

\subsection{The Turkish factor}

Chapter 4.2 faithfully tracked down the development of medieval Arabic cryptology, both the science of secret writing and the different codebreaking techniques offered by scholars, poets and linguists from Damascus and Cairo. The five-hundred-year-old vantage point of Arabs is documented in the series Arabic Origins of Cryptology ${ }^{62}$ It has been also pointed out, how Western cryptology developed independently from the Arabic developments, as a result of the flourishing Italian diplomacy. In other fields of science, Western culture happily profited from Arabic culture (mainly through the translation movement going on in the Iberian Peninsula and Sicily), yet it could not access the fundamental cryptographic works by the Arabs.

The place where the works of Al-Kindi, ibn 'Adlan, ibn Dunaynir, ibn ad-Durayhim, al-Qualquasandi, and a few others actually survived was right there, in the Istanbul collections. The question arises: could the 
Central-European expansion of the Ottoman Empire have opened a new channel of knowledge transfer? Could the Turkish presence in Hungary have introduced cryptographic techniques that were later used in Western practice? Could Hungary in the sixteenth and seventeenth centuries be a place where cryptographic methods were passed on from author to author, just like Spain and Southern-Italy were places where other fields of science were passed on in the eleventh to thirteenth centuries? Could the spies, writers of secret letters or particularly the double agents have been the means of knowledge transfer?

Recent decades have seen extensive studies on early modern Habsburg ${ }^{63}$ and Ottoman ${ }^{64}$ espionage in the Hungarian territories that were divide ed into three parts. ${ }^{6}$ The spies' network spread to all of the areas under Turkish rule, besides the territory of the Hungarian Kingdom under Habsburg control, and the Principality of Transylvania. These agents regularly employed ciphers in their messages. It can be plausibly supposed that they were part of knowledge transfer, especially if they were double

63 Josip Žontar, Obveščevalna služba in diplomacija avstrijskih Habsburžanov v boju proti Turkom v 16. stoleju. Der Kundschafterdinst und die Diplomatie der österreichischen Habsburger im Kampf gegen die Türken im 16. Jahrhundert. (Ljubljana: Slovenska Akademija Znanosti i Umetnosti, 1973). Pál Fodor, "Kémkedés a török korban," (Espionage in the Ottoman era) Keletkutatás 1995: 121-126. Ferenc Szakály, "Egy végvári kapitány hétköznapjai” (Everydays of a fortress captain) in József Kanyar, eds., Somogy Megye Múltjából (From the past of Somogy county) 18 (1987): 45-126. Tivadar Petercsák and Mátyás Berecz, eds., Információáramlás a magyar és török végvári rendszerben (Information flow in the Hungarian and Ottoman fortess systems) (Eger: Dobó István Vármúzeum, 1999), particularly the articles of Géza Pálffy and István Hiller. See also: Dóra Kerekes, "Kémek Konstantinápolyban: A Habsburg információszerzés szervezete és működése a magyarországi visszafoglaló háborúk idején (1683-1699)," (Spies in Constantinople, the organization and functioning of the Habsburg intelligence, 1683-1699) Századok 141 (2007): 1217-1258; eadem, "Hírszerzés a XVI-XVII században," (Intelligence in the 16th-17th centuries) Irodalomismeret 13 (2003): 63-70; eadem, Diplomaták és kémek Konstantinápolyban (Diplomats and spies in Constantinpole (Budapest: L'Harmattan, 2010).

64 Emrah Safa Gürkan, "The efficacy of ottoman counter-intelligence in the 16th century" Acta Orientalia Academiae Scientiarum Hung. 65 (2012): 1-38, Géza Dávid - Pál Fodor, “Oszmán hírszerzés Magyarországon," (Ottoman intelligence in Hungary) in Petercsák-Berecz, Információáramlás, 197-207; Gábor Ágoston, "Információszerzés és kémkedés az Oszmán Birodalomban a 15-17. században," (Intelligence and espionage in the Ottoman Empire in the 15th -17th centuries) in Petercsák-Berecz, Információáramlás, 129-157. Dejanirah Couto, "Spying in the Ottoman Empire: Sixteenth-Century Encrypted Correspondence," in Francisco Bethencourt and Florike Egmond, eds. Cultural Exchange in Early Modern Europe (Volume III) - Correspondence and Cultural Exchange in Europe, 1400-1700 (Cambridge: Cambridge University Press, 2007) 274-312.

65 A helpful historiographical overview: Zoltán Péter Bagi, "A 16-17. századi határvidéki és diplomáciai kémkedés magyar nyelvű irodalmának áttekintése" (Overview on the Hungarian secondary literature on the 16 th $-17^{\text {th }}$ century espionage along the borders and in diplomacy) Aetas 27 (2012): 176-188. 
agents. It is also possible that the cryptographic offices of the enemy, working on the codebreaking of captivated messages, learned from these solved cipher systems.

Some well-known double agents (János Trombitás, ${ }^{66}$ David Passi, ${ }^{67}$ and others ${ }^{68}$ and their stories constitute an especially intriguing chapter of the history of espionage. There has been a significant research on the central and peripheral intelligence organizations: the ways of contact, social status, profession, fate, life and death of spies, and also the content of the acquired information, the enciphered messages, and the effect of the transfer of information. The picture of this area is much more detailed and accurate now than it was two decades ago, but many more hours of archival research is needed to make a complete overview of the intelligence systems in the whole of the early modern era, and to have a clear view of the cipher use of the time. For example, little is known of how the spies had received their code tables that they then had to memorize for the sake of security, ${ }^{69}$ and equally little is known on how frequently they were changing their codes. The first part of these questions could be clarified by further research of the archives, but the second part is not that easily accessible. Ciphered letters were often destroyed, and only the "translated" or plain text versions survived.

On the basis of the presently available information, it seems quite impossible that any cryptologic knowledge was passed on between the Turkish (Arabic) and Western (Hungarian-Habsburg) worlds. What is even more unlikely is that this happened exactly via ciphered correspondence.

First of all, unfortunately it is uncertain whether the above-mentioned Arabic cryptographic handbooks ever got out of the archives of the Ottoman capital. In other words, it is not clear whether any knowledge was passed on between Arabic (of Damascus and Cairo) and Turkish-Ottoman

66 Ferenc Szakály, Mezôváros és reformáció. Tanulmányok a korai magyar polgárosodás kérdéséhez. (Oppidum and Reformation: studies on the early Hungarian formation of bourgeoisie) Budapest, 1995. 225-290.

67 Elif Özgen, "The connected world of intrigues: the disgrace of Murad III's favourite David Passi in 1591", Leidschrift 27 (2012): 75-100; Pál Fodor, "An anti-Semite Grand Vizier? The crisis in Ottoman-Jewish Relations in 1589-91 and its Consequences," in idem, ed., In Quest of the Golden Apple: Imperial Ideology, Politics, and Military Administration in the Ottoman Empire (Istanbul 2000) 191-206.

68 Gürkan, "The efficacy of ottoman counter-intelligence, 28-31.

69 Dóra Kerekes, "Titkosszolgálat volt-e a Habsburgok titkos levelezői intézménye?" (Was the 16-17th Century Habsburg "Secret Correspondence" a Secret Service?) in Csaba Katona, ed. Kémek, ügynökök, besúgók. Az ókortól Mata Hariig. (Szombathely: Magyar Nemzeti Levéltár Vas Megyei Levéltára, 2014): 97-137. 
context. Despite the source publications that are based on thorough background investigations, the provenience of the manuscripts is dubious: the editors did not find the relevant details, or might have not even looked for them. What happened to these manuscripts, where they were kept, whether they were consulted by anyone in the last six or eight centuries remains unclear. In several cases, only one surviving copy is identified anyway, and therefore a likely scenario is that the books were lying on the shelves in Istanbul untouched.

There is further data indicating the lack of knowledge transfer. In 1551 the Turks could not decipher the letters of Johann Malvezzi, the Habsburgs' envoy who had been temporarily captured. The code was too difficult for them. ${ }^{70}$ The Ottoman Turks were so much concerned about the messages that they could not read that between 1560 and 1570 they tried several times to ban the ambassadors of Venice and other cities in Constantinople from sending ciphered messages home. On one occasion, not without any irony, they even ordered the ambassador to teach them the codes, which the ambassador politely refused. ${ }^{71}$ Professional codebreaking was seldom applied, instead they preferred physical aggression towards the people carrying enciphered messages. The Turks also repeatedly asked their French allies to help them decipher a key used by some other nation. ${ }^{72}$

On the one hand, there is no proof then that the Ottoman Turks were in possession of the advanced cryptographic knowledge of the Arabs. On the other hand, there is no sign that the secret agents (double or not) used a technology that was more advanced or newer than the average ciphers of that age. In fact, the secret reports sent to the Habsburg court in the 1630 s are full of outdated graphic symbols instead of the more easily manageable numbers. $^{73}$

The archival research done so far is far from being complete, yet no correlation can be seen at present between the level of cryptographic advancement and the proximity to the Turkish ciphers. The obvious correlation is rather between the development of cryptography and the diplomatic practice.

70 Lajos Kropf, “Malvezzi elfogattatása," (Malvezzi's detention) Századok 30 (1896): 389-393.

71 Gürkan, “The efficacy of ottoman counter-intelligence," 22-23.

72 Communication of Dóra Kerekes.

73 ÖStA HHStA Staatenabteilungen Türkei I. Kt. 112. Konv. 5. fol. 1-9; fol. 17-28. I thank Dóra Kerekes for calling my attention to these sources. 


\subsection{Distance from diplomacy}

The examples quoted at the beginning of this chapter show that "average users" tended to employ monoalphabetic - in a technological sense: outdated - ciphers. The poet Balassi and the merchant Szaniszló were way outside the circles of professional diplomacy. Though with some effort, they could have taken hold of cryptographic handbooks, they saw no need to do so. The savant Johann Heinrich Bisterfeld had easier access to such books, he could probably have just reached for the shelf and opened the Encyclopaedia of his father-in-law, Alsted, to select from the various polyalphabetic methods. Bisterfeld, nevertheless, chose to apply the homophonic methods that were so widespread in the diplomatic practice of the age. A further example is Rákóczi, who used homophonic codes in his correspondence with the French court or his Polish allies, but a more outdated cipher in writing to his generals, just as they (Bercsényi and Károlyi) also used simple graphic and monoalphabetic signs to write to each other that were difficult to use but easy to misunderstand.

However tempting it is to trace early modern Hungarian encrypting practice back to some book-based knowledge, there is no indication that any books from Hungarian collections like Trithemius, Della Porta, and Kircher, or manuscripts hidden in faraway Istanbul like al-Kindi's were actually used in the region. There is ample proof, nevertheless, that the closer someone stood to diplomatic practice, the more likely he was to use advanced, homophonic codes. And the other way around: the further someone was from diplomatic circles, the more likely he was to use less advanced monoalphabetic codes, regardless of his education and experience. The sophisticated ciphers from Della Porta, Vigenère, Selenus, or the Arabic writers were simply and completely disregarded. Early modern cipher users showed no academic interest in the science of cryptography. 
